\title{
UJI AKTIVITAS ANTIBAKTERI EKSTRAK ETANOL BATANG DAN PELEPAH DAUN TANAMAN PISANG AMBON (Musa paradisiaca var sapientum (L.) Kunt ) TERHADAP BAKTERI Staphlyococcus aureus
}

\author{
${ }^{1}$ Claudia L. Adilang, ${ }^{1}$ Nancy Pelealu, ${ }^{1}$ Gayatri Citraningtyas \\ ${ }^{1}$ Program Studi Farmasi FMIPA UNSRAT Manado, 95115
}

\begin{abstract}
Banana is one of the Indonesia native plants which containing acid compounds such as hydroxynnamik, flavanones, flavonols, dopamine and N-Acetylserotonin. Banana plant has many benefits, one of which for herbal medicine. The purpose of this study was to test effect of ethanol extract from the stem and sheathof banana as growth inhibitors of Staphylococcus aureus bacteria and to evaluate, eitherstem or sheath parts of Staphylococcus aureus bacteria. The extraction method of this study using maceration with $96 \%$ ethanol. Based on the results obtained, the ethanol extract of banana steams was batter in inhibits the growth of bacteria of Staphylococcus aureus with the average of clear zone was $10.00 \mathrm{~mm}$ (10\%), $17.00 \mathrm{~mm}(30 \%), 19.00 \mathrm{~mm}(50 \%), 19.33 \mathrm{~mm}(70 \%)$, and $20.33 \mathrm{~mm}(90 \%)$, respectively.
\end{abstract}

Keywords : Musa paradisiaca var sapientum, Antibacterial activity, Staphylococcus aureus.

\begin{abstract}
ABSTRAK
Pisang merupakan salah satu tanaman asli Indonesia yang mengandung senyawa asam hidrosinamik, flavonoid, flavonol, dopamine dan $\mathrm{N}$-asetilserotonin. Bagian dari tanaman pisang memiliki banyak manfaat yang salah satunya untuk obat herbal. Tujuan penelitian ini adalah untuk menguji pengaruh ekstrak etanol dari pelepah dan batang pisang ambon sebagai penghambat pertumbuhan bakteri Staphlyococcus Aureus dan untuk melihat bagian mana dari pelepah atau batang tanaman pisang yang lebih baik dalam menghambat pertumbuhan bakteri Staphlyococcus aureus. Metode ekstraksi dari penelitian ini menggunakan maserasi dengan pelarut etanol 96\%. Ekstrak yang diperoleh diuji aktivitas antibakterinya. Berdasarkan hasil yang diperoleh ekstrak etanol batang tanaman pisang lebih baik dalam menghambat pertumbuhan dari bakteri Staphlyococcus aureus dengan rata-rata zona bening kosentrasi $10 \%$ (10,00 mm), 30\% ( 17,00 mm ), 50\% ( 19,00 mm ), 70\% (19,33 mm ), dan 90\% (20,33 $\mathrm{mm})$.
\end{abstract}

Kata Kunci : Musa paradisiaca var sapientum (L.) Kunt, aktivitas antibakteri, Staphlyococcus aureus. 


\section{PENDAHULUAN}

Salah satu masalah kesehatan yang sedang dihadapi negara-negara maju maupun negara berkembang adalah resistensi terhadap antibiotik, oleh karena itu dibutuhkan beberapa tindakan untuk mengurangi masalah ini. Hal-hal yang dilakukan antaranya adalah mengontrol penggunaan antibiotik, mengembangkan peneitian untuk lebih mengerti tentang mekanisme resistensi secara genetic dan penentuan obat baru baik sintesis maupun yang berasal dari alam (Karadi dkk,2001 ).

Obat tradisional ialah bahan atau ramuan bahan yang berasal dari tumbuhan, hewan, mineral, sediaan sarian ( gelanik ), atau campuran dari bahan tersebut yang secara turun temurun telah digunakan untuk pengobatan secara pengalaman ( Anonim, 2000 ). Indonesia yang beriklim tropis merupakan Negara dengan keanekaragaman hayati terbesar kedua di dunia setelah Brasil. Indonesia memiliki sekitar 25.000-30.000 spesies tanaman yang merupakan $80 \%$ dari jenis tanaman di dunia dan $90 \%$ dari jenis tanaman di Asia ( Pramono, 2002 ). Beberapa tanaman memiliki sifat antibiotic alami untuk beberapa strain bakteri (Nascimeto dkk, 2000 ) seperi ekstrak daun Senna podocarpa, Musa paradisiacal ( pohon pisang ), Allium sativum Linn ( bawang putih ) mampu menghambat bakteri Staphylococcus aureus ( Puspitasari, 2008 ). Staphylococcus aureus merupakan salah satu bakteri potensial pathogen yang pada tubuh manusia dan keadaannya berimbang dengan bakteri lain. Salah satu strain Staphylococcus aureus yang berbahaya adaah Methidilin-tesistan Staphylococcus aureus(MRSA) bakteri ini sering ditemukan pada berbagai tingkat penyakit mulai yang ringan, noninvasive skin and soft tissiu infection( SSTIS ) sampai bentuk invasive bahkan sampai bakteriemia. Selain itu, Staphylococcus aureus merupakan salah satu bakteri yang resisten terhadap beberapa jenis antibiotic terutama golongan B-laktam. Resistensi bakteri terhadap antibiotic menyebabkan peningkatan biaya rumah sakit dan menyebabkan pengobatan yang tidak memenuhi syarat sering terjadi pada negara berkembang ( Valarmathy dkk, 2010 ).

Indonesia mempunyai banyak jenis tanaman yang berpotensi sebagai antibiotic, salah satunya adalah tanaman pisang.Indonesia merupakan habitat yang sesuai untuk tanaman pisang karena iklimnya yang tropis.Tanaman pisang mempunyai bagian-bagian diantaranya adalah akar, batang, pelepah, daun, bunga, dan buah. Pelepah tanaman pisang biasanya dimanfaatkan oleh bebrapa masyarakat di Indonesia sebagai obat luka, beberapa bagian lain dari tanaman pisang telah diteliti manfaatnya diantaranya adalah ekstrak batang tanaman pisang ambon bermanfaat untuk mempercepat penyembuhan luka pada mencit ( Prasetyo dkk, 2010 ). Ekstrak kulit buah pisang dan daunnya dapat menghambat pertumbuhan beberapa bakteri pathogen seperti Staphylococcus aureus (Vaarmathy dkk, 2010).

Kemampuan menghambat pertumbuhan bakteri dan mempercepat penyembuhan luka dimungkinkan karena adanya senyawa aktif yang terkandung didalam getah tanaman pisang diantaranya yaitu asam hidrosinamik, flavonoid, flavonol, dopamine dan $\mathrm{N}$-asetilserotonin ( Pongsagon dkk, 2010 ). Informasi penggunaan bagian lain dari tanaman pisang seperti pelepah, batang dan akar tanaman pisang sebagai anti bakteri masih sangat sedikit, oleh karena itu peneliti 
terterik untuk melakukan penelitian penggunaan ekstrak etanol pelepah daun dan batang tanaman pisang ambon serta menguji aktivitas pada bakteri Staphylococcus aureus sehingga nantinya diketahui bagian batang atau pelepah daun ekstrak etanol tanaman pisang ambon yang paling baik aktivitas antibakterinya.

\section{METODOLOGI PENELITIAN}

Alat

Alat-alat yang digunakan selama proses penelitian yaitu rotary evaporator, erlenmeyer, gelas ukur, gelas kimia, batang pengaduk, timbanagn analitik, pisau, aoutoclav, tabung reaksi, pipet, mikro pipet, kertas saring, cawan petri, lampu Bunsen dan korek api, wadah toples, alumunium foil, hot plate, laminar air flow, blender, ayakan mesh 65, corong, pinset, gunting, incubator, pencadang, dan jarum osse.

\section{Bahan}

Bahan yang digunakan ekstrak etanol batang dan pelepah daun pisang ambon (Musa paradisiacal var Sapientum (L) Kunt), etanol 96\%, tablet ciprofloxacin $500 \mathrm{mg}$. H2SO4 0,36 N, BaCl2.2H2O $1,175 \%$, suspense bakteri S.aureus, nutrient agar $(\mathrm{Na})$, alcohol, $\mathrm{NaCl} 0,9 \%$, aquades, kapas, kertas label, sarung tangan, masker, tissue.

\section{Pengambilan Sampel}

Sampel yang digunakan dalam penelitian ini yaitu batang dan pelepah daun tanaman pisang ambon. Sampel diambil di daerah Bitung, Sulawesi Utara. Sampel dibersihkan dan dirajang kasar, kemudian dikeringkan dengan cara diangin-anginkan. Sampel yang telah kering dibuat menjadi serbuk dengan menggunakan blander lalu serbuk yang dihasilkan diayak menggunakan ayakan mesh 65 sehingga diporoleh serbuk yang halus dan seragam. Hasilnya dimasukkan ke dalam wadah gelas tertutup.

\section{Identifikasi Tanaman}

Identifikasi tanaman dilakukan di Laboratorium Taksonomi Tumbuhan, Jurusan Biologi Fakultas Matematika dan ilmu Pengetahuan Alam, Universitas Sam Ratulangi Manado.

\section{Ekstraksi}

Ekstraksi dilakukan dengan menggunakan metode maserasi dan mengguanakn pelarut etanol 96\%.Ekstraksi dilakukan dengan melarutkan $100 \mathrm{~g}$ sampel dalam $750 \mathrm{~mL}$ pelarut, untuk pelepah daun diberi label $\mathrm{P}$ dan untuk batang diberi label $B$. Perendaman dilakukan selama 5 hari sambil sesekali diaduk. Setelah 5 hari masing-masing sampel disaring mengguanakn kertas saring, menghasilakan filtrate P1 dan B1 serta residu P1 dan B1. Residu yang ada kemudian diremaserasi dengan $250 \mathrm{~mL}$ pelarut selama 2 hari. Setelah 2 hari sampel disaring kembali mengguanakn kertas saring menghasilkan filtrate P2 dan B2 serta ampas. Filtrate P1 dan P2 dicampur menjadi satu, begitu juga dengan B1 dan B2. Kemudian filtrat yang diperoleh diuapkan dengan menggunakan rotary evaporator sehingga diperoleh ekstrak etanol dari masing-masing sampel.

\section{Sterilisasi Alat}

Alat-alat yang digunakan dalam penelitian aktivitas antibakteri ini disterilkan terlebih dahulu. Alat-alat gelas disterilkan dalam autoclave pada suhu $121^{\circ} \mathrm{C}$ selama 15 menit, pinset dan jarum osse dibakar dengan pembakaran 
langsung dan media disterilkan dalam autoklaf pada suhu $121^{\circ} \mathrm{C}$ selama 15 menit.

\section{Pembuatan Standar Kekeruhan (Larutan Mc.Farland)}

Larutan $\mathrm{H} 2 \mathrm{So} 4 \quad 0,36 \%$ N sebanyak 99,5 $\mathrm{mL}$ decampurkan dengan $\mathrm{BaCl} 2.2 \mathrm{H} 2 \mathrm{o} \quad 1,175 \%$ sebanyak $0,5 \mathrm{~mL}$ dalam tabun. Tabung dikocok sampai terbentuk larutan keruh.Kekeruhan ini dipakai sebagai standar kekeruhan bakteri (Victor, 1980).

\section{Pembuatan Larutan Kontrol Positif (+) dan Kontrol (-)}

Larutan control (+) ialah ciprofloxacin yang dibuat dengan cara 1 trablet Ciprofloxacin $500 \mathrm{mg}$ dihaluskan, setelah itu ditimbang $0,5 \mathrm{~g}$ dan dilarutkan dalam $100 \mathrm{~mL}$ aquades, dengan cara diambil $1 \mathrm{~mL}$ latutan dan ditambahkan aquades sampai $10 \mathrm{~mL}$ dikocok. Kosentrasi ini digunakan sebagai control posif (+) pada pengujian. Larutan control negative (-) dibuat menggunakan aquades. Control negative digunakan sebagai perbandingan dan pelarut untuk pembuatan larutan control posif dan pembuatan larutan uji.

\section{Pembuatan Larutan Uji}

1. Larutan uji kosentrasi $10 \%$ : ditimbang ekstrak $0,1 \mathrm{~g}$ kemudian dilarutkan dalam $1 \mathrm{~mL}$ aquades.

2. Larutan uji kosentrasi $30 \%$ : ditimbang ekstrak 0,3 g kemudian dilarutkan daalm $1 \mathrm{~mL}$ aquades.

3. Larutan uji kosentrasi $50 \%$ : ditimbang ekstrak 0,5 g kemudian dilarutkan dalam $1 \mathrm{~mL}$ aquades.
4. Larutan uji kosentrasi $70 \%$ : ditimbang ekstrak $0,7 \mathrm{~g}$ kemudian dilarutrkan daalm $1 \mathrm{~mL}$ aquades.

5. Larutan uji kosentrasi 90\% : ditimbang ekstrak 0,9 g kemudian dilarutkan dalam $1 \mathrm{~mL}$ aquades.

\section{Pembuatan Media}

a. Media dasar dan peremajaan bakteri adalah sebagai berikut :

1) Nutrient agar ditimbang sebanyak 23 gram dilarutkan dalam $100 \mathrm{~mL}$ aqudes kemudian dipanaskan diatas hot palte sampai mendidih dan diperoleh larutan jernih.

2) Media (2 tabung reaksi yang berisi $5 \mathrm{~mL}$ ) selanjutnya dibiarkan dingin dan mengeras pada kemiringan $30^{\circ}$ (agak miring).

3) Bakteri Staphylococcus aureus diinokulasi pada media miring menggunakan kawat osse kemudian diikubasi dalam incubator pada suhu $37^{\circ} \mathrm{C}$ selama $1 \times 24$ jam.

b. Media Pembenihan

Pembuatan media pembenihan dilakukan melalui tahap sebagai berikut :

Nutrien agar ditimbang sebanyak $23 \mathrm{~g}$ dalam $100 \mathrm{~mL}$ aqudes dan dipanaskan diatas hot plate sambil diaduk sampai mendidih kemudian disterilkan dalam autoklaf pada suhu $121^{\circ} \mathrm{C}$ selama 15 menit. Media dituang kedalam 6 tabung reaksi (masing-masing tabung reaksi berisi $15 \mathrm{~mL}$ ).

c. Pembuatan Suspensi bakteri Uji

Bakteri uji yang telah diinokulasi diambil dengan kawat osse steril 
lalu disuspensikan kedalam tabung yang berisi $2 \mathrm{~mL}$ larutan $\mathrm{NaCl} \quad 0,9 \%$ hingga diperoleh kekeruhan yang sama dengan standar kekeruhan larutan Mc.Farland.

\section{Pengujian Aktivitas Antibakteri}

Pengujisn sktivitas antibakteri dilakukan dengan menggunakn metode difusi, dengan cara melarutkan ekstrak batang dan pelepah daun pisang ambon, dengan pelarut etanol, serta larutan control (+) dan control (-), dengan prosedur kerja sebagai berikut :

Media nutrient agar (NA) dituang kedalam cawan petri sebanyak $10 \mathrm{~mL}$ dan dibiarkan mengeras.Pada permukaan lapisan dasar diletakan 7 pecadang dan diatur sedemikian rupa sehingga terdapat daerah yang cukup untuk mengamati zone hambat yang terjadi. Pada setiap cawan petri dituang $15 \mathrm{~mL}$ media pembenihan NA disekeliling pecadang, cawan petri diputas $\pm 60^{\circ} \mathrm{C}$ sebanyak $3 \mathrm{x}$ sehingga membentuk lapisan yang rata dan dibiarkan memadat. Dikeluarkan pecadang dari cawan petri sehingga terbentuk sumur. Dengan menggunakan mikropipet, masing0masin sumur diteteskan larutan uji ekstrak etanol, control positif dan control negative, setelah itu diinkubasi dalam incubator pada suhu $37^{\circ} \mathrm{C}$ selama $1 \times 24$ jam.

\section{Pengamatan}

Setelah 1x24 jam, diamati zona hambat yang terbentuk disekitar sumur kemudian diukur diameter zona hambat secara horizontal dan vertical dengan menggunakan mistar berkala.

\section{Teknik Penumpulan Data dan Analisa Data}

- Pengumpulan data dilakukan dengan mengukur diameter zona hambat dari masing-masing kosentrasi pada inkubasi selama 1x24 jam.Data dianalisa secara deskriptif.

\section{HASIL DAN PEMBAHASAN \\ Identifikasi Tanaman}

Identifikasi sampel batang dan pelepah daun tanaman pisang ambon dilakukan di Laboratorium taksonomi Tumbuhan Program Studi Biologi FMIPA UNSRAT Manado. Hal ini dilakukan untuk membuktikan kebenaran sampel tumbuhan batang dan pelepah daun pisang ambon. Hasil yang diperoleh menunjukan bahwa sampel yang digunakan ialah batang dan pelepah daun tanaman pisang ambon (Musa paradisiacal var sapientum(L) Kunt).

\section{Preparasi Sampel}

Batang dan pelepah daun tanaman pisang ambon dibersihkan dan dicuci dahulu dengan air mengalir sampai bersih. Hal ini bertujuan untuk membersihkan sampel dari sisa-sisa pengotor yang bias merusak sampel. Setelah dibersihkan sampel dirajang sehingga diproleh sampel dalam ukuran yang lebih kecil. Tujuan dari perajangan sampel ialah untuk mempercepat proses pengeringan dan mempermudah dalam prose penghalusan sampel. Menurut Anonim 1985, sampel yang dikeringkan dengan cara dianginanginkan bertujuan untuk menurunkan kadar air sampel dan menjaga senyaea aktif yang tidak tahan terhadap pemanasan langsung. Setelah itu sampel dihaluskan dengan menggunkan blender. Pembuatan serebuk bertujuan untuk memperluas pewrmukaan yang berinteraksi dengan 
pelarut sehingga lebih banyak senyawa yang dapat terekstraksi.

\section{Hasil Ekstraksi}

Batang dan pelepah daun tanaman pisang ambon diekstraksi dengan menggunakn metode maserasi dan diperoleh ekstrak batang sebanyak 2,7 g dan pelepah daun sebanyak 3,1 g. Ekstrak yang telah didapatkan tersebut diperoleh dari serbuk simplisia batang yang ditimbang sebanyak $100 \mathrm{~g}$ lalu dilarutkan dalam $1000 \mathrm{~mL}$ etanol 96\%, dan simplisia pelepah yang ditimbang sebanyak $100 \mathrm{~g}$ lalu dilarutkan dalam $1000 \mathrm{~mL}$ etanol 96\%. Kemudian dilakukan maserasi selama 7 hari dengan pertgantian pelarut pada hari ke 5 dan diremaserasi kembali selama 2 hari, setelah itu menghasilakn filtrate batang sebanyak $815 \mathrm{~mL}$ dan filtrate pelepah sebanyak $835 \mathrm{~mL}$ kemudian diuapkan di rotary evaporator, setelah itu dimasukkan kedalam oven dengan suhu $40^{\circ} \mathrm{C}$.

\section{Uji Aktivitas Antibakteri Etanol Batang dan Pelepah Daun Tanaman Pisang Ambon}

Table 1.Hasil Pengukuran Diameter Zona Hambat Ekstrak Etanol Batang Tanaman Pisang Ambon (Musa Paradisiaca var Sapientum (L) Kunt) terhadap bakteri Staphylococcus aureus.

\begin{tabular}{|c|c|c|c|c|}
\hline Kosentrasi & \multicolumn{3}{|c|}{$\begin{array}{c}\text { Diameter Zona Hambat } \\
(\mathrm{mm})\end{array}$} & $\begin{array}{c}\text { Rata- } \\
\text { rata }\end{array}$ \\
\hline & $\mathrm{B} 1$ & $\mathrm{~B} 2$ & $\mathrm{~B} 3$ & \\
\hline Kontrol (-) & 0 & 0 & 0 & 0,00 \\
\hline Kontrol (+) & 26,00 & 27,00 & 25,00 & 26,33 \\
\hline $\begin{array}{c}\text { Kosentrasi } \\
10 \%\end{array}$ & 9,00 & 10,00 & 11,00 & 10,00 \\
\hline $\begin{array}{c}\text { Kosentrasi } \\
30 \%\end{array}$ & 17,00 & 15,00 & 19,00 & 17,00 \\
\hline $\begin{array}{c}\text { Kosentrasi } \\
50 \%\end{array}$ & 20,00 & 18,00 & 19,00 & 19,00 \\
\hline $\begin{array}{c}\text { Kosentrasi } \\
70 \%\end{array}$ & 18,00 & 22,00 & 18,00 & 19,33 \\
\hline $\begin{array}{c}\text { Kosentrasi } \\
90 \%\end{array}$ & 20,00 & 22,00 & 19,00 & 20,33 \\
\hline
\end{tabular}

Table 2.Hasil Pengukuran Diameter Zona Hambat Ekstrak Etanol Pelepah Daun Tanaman Pisang Ambon (Musa Paradisiaca var Sapientum (L) Kunt) terhadap bakteri Staphylococcus aureus.

\begin{tabular}{|c|c|c|c|c|}
\hline Kosentrasi & \multicolumn{3}{|c|}{$\begin{array}{c}\text { Diameter Zona Hambat } \\
(\mathrm{mm})\end{array}$} & $\begin{array}{c}\text { Rata- } \\
\text { rata }\end{array}$ \\
\hline & $\mathrm{P} 1$ & $\mathrm{P} 2$ & $\mathrm{P} 3$ & \\
\hline Kontrol (-) & 0 & 0 & 0 & 0,00 \\
\hline Kontrol (+) & 23,00 & 25,00 & 27,00 & 25,00 \\
\hline $\begin{array}{c}\text { Kosentrasi } \\
10 \%\end{array}$ & 0 & 0 & 0 & 0 \\
\hline $\begin{array}{c}\text { Kosentrasi } \\
30 \%\end{array}$ & 0 & 0 & 0 & 0 \\
\hline $\begin{array}{c}\text { Kosentrasi } \\
50 \%\end{array}$ & 10,00 & 11,00 & 11,00 & 10,67 \\
\hline $\begin{array}{c}\text { Kosentrasi } \\
70 \%\end{array}$ & 11,00 & 12,00 & 11,00 & 11,33 \\
\hline $\begin{array}{c}\text { Kosentrasi } \\
90 \%\end{array}$ & 12,00 & 23,00 & 11,00 & 12,00 \\
\hline
\end{tabular}

Pada penelitian ini dilakukan proses ekstraksi dengan menggunakan metode maserasi karena memiliki keunggulan yaitu cara pengerjaan yang cepat, peralatan yang digunakan sederhana, relatif mudah dan murah. Selain itu pemilihan metode ekstraksi secara maserasi didasarkan pada ada tidaknya senyawa yang bersifat tidak tahan panas (Gandjar dan Abdul, 2008).

Dalam proses maserasi, sel tumbuhan mengalami kondisi terdesak, sehingga sel-sel akan mengeluarkan zat aktif yang akan diikat oleh pelarut. Proses maserasi sesekali dilakukan pengadukan dengan tujuan terjadi kontrak antara pelarut dengan rongga yang ada dalam sel tumbuhan sehingga senyawa dalam tumbuhan tersebut dapat keluar. Proses maserasi dilakukan selama 7 hari dengan pergantian pelarut pada hari ke 5 dan dimaserasi kembali selama 2 haridengan tujuan agar senyawa kimia yang terkandung dalam tanaman dapat tertarik 
secara maksimal. Kemudian didapatkan filtrate yang diuapkan dirotary evaporator dan dimasukkan dalam wadah setelah itu dikeringkan dalam oven pada suhu $40^{\circ} \mathrm{C}$ tujuannya agar tidak merusak senyawa yang terkandung didalam ekstrak, sehingga diperoleh massa konstan yang disebut ekstrak kental.

Pelarut yang digunakan adalah etanol karena merupakan pelarut universal, pelarut ini dapat melarutkan hamper maupun semua senyawa organic yang ada pada sampel, baik senyawa polar maupun senyawa non polar (Shadmani dkk., 2004). Etanol juga digunakan sebagai pelarut karena lebih selektif untuk melarutkan flavonoid, alkaloid, tannin, saponin dan minyak atsiri.

Uji aktifitas antibakteri ekstrak etanol batang dan pelepah daun tanaman pisang ambon (Musa Paradisiaca var Sapientum (L) Kunt) terhadap bakteri Staphylococcus aureus menggunakan metode difusi agar. Difusi agar menggunakan media NA karena media NA adalah media umum dalam pertumbuhan bakteri karena pada media NA dapat memudahkan bakteri untuk berkembang biak. Sempel yang digunakan dalam penelitian ini adalah ekstrak etanol batang dan pelepah daun tanaman pisang ambon dan diencerkan menjadi lima kosentrasi yaitu $10 \%, 30 \%, 50 \%, 70 \%$, dan $90 \%$ untuk masing-masing sampel. Bakteri diujikan kepada masing-masing kosentrasi untuk melihat apakag ada perbedaan diameter zona bening yang terbentuk pada masing-masing ekstrak.

Kontrol negative yang digunakan ialah aquades steril dan hasil yang diperoleh tidak memberikan efek antibakteri pada kedua bakteri uji. Pada control positif hasil menunjukan terbentuknya zona bening pada cawan petri dan hasil yang diperoleh lebih besar dari kelima seri kosentrasi dimana control posotif yang digunakan adalah ciprofloxacin $50 \mu \mathrm{g} / \mu \mathrm{L}$.

Menurut Jawetz dkk (2007), ciprofloxacin memiliki efek antibakteri yang besar (spectrum luas). Hasil penelitian menunjukkan bahwa diameter zona hambat yang dibentuk oleh ciprofloxacin lebih besar pada bakteri Staphylococcus aureuspenggujian dengan menggunakan ekstrak pelepah daun $(25,00$ $\mathrm{mm}$ ) dan pengujian dengan menggunakan ekstrak batang $(26,33 \mathrm{~mm})$. mekanisme kerjanya dengan menghambat topoisomerase II (=DNA girase) dan topoisimerase II berfungsi menimbulkan relaksasi dan DNA yang mengalami positive supercoilingpada waktu transkrip dalam proses replikasi DNA. Dari hasil tersebut dapat dilihat bahwa bakteri dan karekteristik yang berbeda-beda dalam menghambat pertumbuhan bakteri.Staphylococcus aureuspada kosentrasi eksrak memiliki sifat dan karakteristik yang berbeda-beda dalam menghambat pertumbuhan bakteri.

Berdasarkan pengujian atau penelituan yang telah dilakukan ternyata ekstrak batang tanaman pisang ambon lebih baik dalam menghambat pertumbuhan bakteri Staphylococcus aureuskarena telah memiliki kemampuan menghambat mulai dari kosentrasi yang paling kecil yaitu $10 \%$ dan memiliki kenaikan yang etratur pada masing-masing kosentrasi. Sedangkan pada ekstrak pelepah daun tanaman pisang ambon hanya memiliki aktifitas antibakteri pada kosentrasi 50\%, 70\% dan 90\%. Hal ini dikarenakan pada batang pisang memiliki atau mengandung lebih banyak getah pisang dibandingkan dengan pelepah daun pisang.Getah pisang mengandung saponin, 
antrakuinon, dan kuinolon yang dapat berfungsi sebagai antibiotic dan penghilang rasa sakit.Selain itu, terdapat pula kandungan lektin yang berfungsi untuk menstimulasi pertumbuhan sel kulit.Kandungn-kandungan tersebut dapat membunuh bakteri agar tidak dapat masuk pada bagian tubuh kita yang sedang mengalami luka.Getah pisang berfungsi mendingikan.Zat tannin pada getah batang pisang bersifat antiseptic, sedangkan zat saponin berkhasiat mengencerkan dahak.

Menurut Ajizah dkk (2004), selain factor kosentrasi, jenis bahan antimikroba juga menentukan kemampuan menghambat pertumbuhan bakteri. Pada penelitian ini, kemampuan untuk menghambat pertumbuhan bakteri dari ekstrak etanol batang dan pelepah daun tanaman pisang ambon (Musa Paradisiaca var Sapientum (L) Kunt) diduga karena adanya kandungan senyaw-senyawa yang berkhasiat sebagai antibakteri seperti flavonoid, polifenol, alkaloid dan minyak atsiri.

\section{KESIMPULAN}

Berdasarkan hasil penelitian yang telah dilakukan dapat disimpulkan bahwa pengaruh ekstrak etanol batang dan pelepah daun terhadap :

1. Ekstrak etanol batang dan pelepah daun tanaman pisang ambon (Musa Paradisiaca var Sapientum (L) Kunt) dapat menghambat pertumbuhan bakteri Staphylococcus aureus.

2. Ekstrak etanol batang tanaman pisang ambon (Musa Paradisiaca var Sapientum (L) Kunt) lebih baik dalam menghambat pertumbuhan bakteri Staphylococcus aureus.

\section{SARAN}

Setelah melakukan penelitian ini, maka disarankan untuk penelitian selanjutnya :

1. Perlu dilakukan penelitian lebih lanjut mengenai efektifitas ekstrak etanol batang dan pelepah daun tanaman pisang ambon (Musa Paradisiaca var Sapientum (L) Kunt) terhadap jenis bakteri lain.

2. Perlu dilakukan penelitian lebih lanjut mengenai pengujian efektifitas ekstrak etanol batang dan pelepah daun tanaman pisang ambon (Musa Paradisiaca var Sapientum (L) Kunt) dengan menggunakan pengujian metode lain seperti dilusi.

\section{DAFTAR PUSTAKA}

Anonim. 2000. Pedoman Pelaksanaan Uji Klinik Obat Traisional. Direktorat Jendral Pengawasan Obat dan Makanan, Direkrorat Pengawasan Obat Tradisional.

phytochemical and pharmacological review. Journal of Applied Pharmaceutical Science 01(05): 14-20.

Karadi R. V, Arpan Shah, Pranav Parekh dan Parvez Azmi. Antimicrobial Activities of Musa paradisiaca and Cocos nucifera. International Journal of Research in Pharmaceutical and Biomedical Sciences.vol 2: 264-267.2011 URL:

www.ijrpbsonline.com/files/032.pd $\mathrm{f}$

K.Valarmathy , P.Azhagu Saravan Babu, M.Abhilash. Antimicrobal Activity of Ethanolic Extract of Various Plant Leaves Against Selected 
Microbal Species. Electronic journal of environmental, Agricultural and food chemistry vol 1(8)293-295.2010 URL: www.ijpsr.info/docs/IJPSR10-0108-14.pdf

Nascimento G.F.Gislene, Juliana Locatelli, Paulo C. Freitas, Giuliana L. Silva. Antibacterial Activity of Plant Extracts and Phytochemicals on Antibiotc Resistant Bacteria. Brazilian Journal of Microbiology 31:247-256.2000 URL http://www.scielo.br/pdf/bjm/v31n 4/a03v31n4.pdf

Pongsagon Pothavorn, Kasipong Kitdamrongsongt, Sasivimon Swangpol, Siripope Wongniam, Kanokporn Atawongsa, Jisnuson Svasti and Jamorn Somana. Phytochemical Compositions of Some Bananas in Thailand. J. Agric. Food Chem Vol. 58, No. 15 8782-8787.2010 http://pubs.acs.org/doi/abs/10.1021 /jf

Pramono E. 2002. The Commercial Use of Traditional Knowledge and Medicinal Plants in Indonesian. Submitted for multi-stakholder dialoque on trade, intellectual property and biological resources in Asia.

Puspitasari.I. 2008. Uji Aktivitas Antibakteri Bawang Putih (Allium sativum Linn) terhadap Bakteri Staphylococcus aureus In Vitro.

Victor, L., 1980. Antibiotics in Laboratory Test. The Williams and Wilkins Company. USA. 